\title{
A QUESTÃo DE DEUS NA FENOMENOLOGIA HERMENÊUTICA DE JEAN-LUC MARION
}

\author{
THE QUESTION OF GOD IN THE HERMENEUTIC \\ PHENOMENOLOGY OF JEAN-LUC MARION
}

SAMUEL DIMAS

Universidade Católica Portuguesa

Recibido: 04/07/2020 Aceptado: 23/09/2020

\section{RESUMO / RESUMEN}

A partir da análise da obra de Jean-Luc Marion, procuramos identificar neste estudo a possibilidade de um diálogo entre a filosofia e a teologia através da relação entre a fenomenologia, a hermenêutica e a metafísica. Excedendo os horizontes da objetividade e da enticidade da metafísica tradicional e excedendo o plano da redução à intencionalidade da fenomenologia ortodoxa, o pensamento do filósofo francês estende-se pelos domínios do espiritualismo existencialista e personalista, considerando a alteridade do outro como doação e cuja evidência encerra uma dimensão invisível e infinita, não passível de absoluta determinação.

Palavras Chave / Palabras clave: fenomenologia, metafísica, doação, afetividade, hermenêutica, teologia. 


\section{ABSTRACT}

Based on analysis of the work of Jean-Luc Marion, in this study we seek to identify the scope for a dialogue between philosophy and theology through the relationship between phenomenology, hermeneutics and metaphysics. Reaching beyond the horizons of objectivity and the entities of traditional metaphysics and exceeding the scale of reduction of intentionality in orthodox phenomenology, the thinking of this French philosopher extends over the domains existentialist and personalist spiritualism, considering the alterity of the other as a donation and whose evidence encloses a invisible and infinite dimension not susceptible to any absolute determination.

Keywords: phenomenology, metaphysics, donation, affectivity, hermeneutics, theology.

\section{INTRODUÇÃO: PARA UMA FENOMENOLOGIA HERMENÊUTICA DA DOAÇÃO E DA EXCEDÊNCIA}

O pensamento de Jean-Luc Marion insere-se no âmbito da corrente fenomenológica francesa contemporânea de autores como Emmanuel Levinas, Paul Ricoeur, Michel Henry e Jean-Louis Chrétien, tendo como principal preocupação conciliar a fenomenologia com a hermenêutica, na tarefa de superar os limites do horizonte intencional através de uma abertura para a realidade invisível do absoluto outro, cuja alteridade não é adequada à ideia ${ }^{1}$. Será que este projeto terá como consequência uma necessária relação entre a fenomenologia hermenêutica e a metafísica?

Sem recusar em absoluto a metodologia da fenomenologia clássica, assente nas noções de "redução", "intencionalidade" e "constituição", o trabalho de Marion já não se situa dentro dos antigos horizontes da objetividade e da enticidade, estendendo-se pelos domínios da teologia, do existencialismo, do personalismo, do espiritualismo e da hermenêutica com a passagem do primado da "consciência transcendental" para a "doação" em que a "possibilidade" fica liberta de qualquer restrição ${ }^{2}$.

Esta posição implica uma primazia do "mostrar", em relação ao "demonstrar", de um fenómeno que se dá na experiência como "acontecimento" sem se adequar

1 Jorge Luis Roggero, Hermenéutica del amor - La fenomenologia de la donación de Jean-Luc Marion en diálogo com la fenomenologia del joven Heidegger (Buenos Aires: Sb editorial, 2019), 25.

$2 \quad$ Ibid., 31. 
às estruturas a priori do sujeito cognoscente. Sabemos que a recusa do processo argumentativo num método puramente indutivo, em que o mostrar-se não tem outro critério de validade que o seu simples mostrar-se, pode conduzir à dissolução do discurso fenomenológico em outros discursos, como o artístico, o psico-analítico ou o religioso. Não estará Marion a correr o risco de um discurso puramente empírico, em que o dado surge como imediato e indubitável (sense data), justificando-se a si mesmo, sem se tonar objeto de uma operação de verificação eidética?

\section{A FENOMENOLOGIA NO SENTIDO HEIDEGGERIANO DE AUTODOAÇÃO}

Em resposta a esta última questão, Jean-Luc Marion considera que o "dado" não deve ser entendido no sentido empírico de sense data, explicando que não é imediato nem mediato, mas que inclui um certo carácter indeterminado, distinguindo-se dos objetos e conhecimentos, uma vez que estes são antecedidos pelo seu acontecimento ${ }^{3}$. Assim, o autor não segue a ortodoxia do método fenomenológico delimitado por Husserl, mas pressupõe a definição de Heidegger de que a fenomenologia é a permanente possibilidade de se pensar em correspondência com aquilo que faz pensar. Por distinção com a posição ortodoxa alemã, que delimita a fenomenologia nas fronteiras da "intuição doadora originária" e do "horizonte do Dasein", a perspetiva francesa exige uma nova ampliação na preferência do infinito sobre o finito e do invisível sobre o visível ${ }^{4}$.

Em diálogo com Heidegger, que no parágrafo 7 de Sein und Zeit define o fenómeno como "o-que-se-mostra-em-si-mesmo"5, o pensador francês procura descrever a espontaneidade imediata da vivência sem interromper o seu fluxo mediante a reflexão conceptual generalizadora e objetivante. Para tal recorre ao exercício fenomenológico em que aquilo que se dá de imediato não é a necessidade da construção de um significado, mas sim o mundo circundante já repleto de significados. O acesso a essa realidade é dado pela "intuição compreensiva" que é prévia às distinções do domínio teórico-reflexivo e que respeita o ritmo das vivências, tendo como forma ideal de tradução ou comunicação as metáforas sonoras. Assim, o fenómeno que nos permite o genuíno acesso às coisas é o que se mostra como tal no seu mostrar-se a si mesmo de forma

3 Jean-Luc Marion, Réduction et donation. Recherches sur Husserl, Heidegger et la phénoménologie (Paris: PUF, 1989), 78.

4 Emmanuel Falque, Le combat amoureux. Disputes phénoménologiques et théologiques (Paris: Hermann, 2014), 16.

5 Martin Heidegger, Gesamtausgabe, 2 (Frankfurt: Vittorio Klostermann Verlag, 1989), 38. 
patente ou na modalidade latente de encobrimento. $\mathrm{O}$ regresso às coisas mesmas não significa, como em Husserl, o retorno à evidência da intuição na consciência, no pressuposto de um sentido idealista de verdade como adaequatio e da objetividade como produto das operações do pensamento.

É evidente a relação entre a fenomenologia de Marion, que propõe substituir a metafísica na procura de um novo começo que não está na ousía de Aristóteles, não está na causa de Tomás de Aquino, nem está no cogito de Descartes, e a fenomenologia apresentada por Heidegger nos seus primeiros cursos, anteriores à pergunta pelo ser como novo horizonte que se impõe à manifestação dos fenómenos. Nas suas primeiras reflexões, nomeadamente no curso do semestre de Inverno de 1919-1920, Heidegger critica a objetivação e propõe uma radicalização da própria fenomenologia contra si mesma, no sentido de não se perder na periferia de questões especializadas, mas de regressar às fontes originárias dos problemas ${ }^{6}$. Contra a ciência rigorosa entendida como uma conceção objetivante, Marion segue esta proposta de uma compreensão radical do método como "contra-método" 7 na procura de regressar à origem das possibilidades fundamentais com acesso à esfera pré-teorética da doação, em que o fenómeno é portador da capacidade de se manifestar a partir de si mesmo.

Dessa maneira, Marion eleva a noção de "doação", que defende encontrar na expressão gegebenheit de Husserl e na expressão geben de Heidegger, ao nível de princípio absoluto, não a limitando ao "facto de ser dado à consciência", mas abrindo-a a um alcance metafísico ${ }^{8}$. Sabemos que esta abertura da fenomenologia à metafísica já está presente na obra do próprio Husserl quando apresenta a "teleologia" e "Deus" como os fenómenos principais da esfera "meta-histórica".

Importa, no entanto, advertir que a "doação" é concebida pelo autor como um processo de fenomenalização e não como um dado ôntico, no sentido de uma modalidade de produção, ou como uma fundação ontoteológica no sentido bíblico da Criação ${ }^{10}$. O objeto enquanto conhecível não se define pelo seu ser ou pela sua consistência, mas pela sua doação ${ }^{11}$. Mas para aceder ao âmbito originário e préteorético da "doação", que não nos está dado à partida, é necessário aplicar um

6 Heidegger, Gesamtausgabe, 58, 6.

7 Jean-Luc Marion, Étan donné - Essai d'une phénoménologie de la donation (Paris: PUF, 2023) $11-16$.

8 Marie-André Ricard, "La question de la donation chez Jean-Luc Marion”, Laval Théologie et philosophie, 57 (2001), 94. 81-103.

10 Jean-Luc Marion, Figures de phénoménologie: Husserl, Heidegger, Levinas, Henry, Derrida (Paris, Vrin, 2012), 28.

11 Ibid., 40. 
método que se entregue ao fenómeno sem lhe impor termos ou teorias a priori. Nessa entrega, o que se mostra já não é um objeto nem uma coisa, mas uma significação num mundo circundante ${ }^{12}$.

Para Jean-Luc Marion, para além dos "fenómenos pobres" que apenas requerem uma intuição formal matemática ou uma intuição categorial lógica e se dão na inteligibilidade conceptual, para além dos "fenómenos de direito comum", objetos da física e das ciências naturais e objetos industriais, há "fenómenos de tipo de acontecimento" que contêm um excesso de intuição em relação à intenção e não se deixam constituir em objetos: são os "fenómenos saturados" ou "paradoxais" (contra a opinião corrente e a experiência vulgar de representação) que não se restringem às condições de um horizonte pré-determinado e de um Eu constituinte $^{13}$. Para além dos "fenómenos saturados simples", como o ídolo, o ícone e a carne, também há os "fenómenos de revelação". A ciência produz certezas provisórias sobre aquilo que pode ser reduzido a objeto por via do uso predicativo e categorial da linguagem ${ }^{14}$, e a religião produz certezas místicas e dogmáticas de carácter definitivo, mas o que nos advém sem causa identificável e sem razão previsível, que excede as capacidades humanas cognoscitivas, situase no plano daquilo que Marion chama as "certezas negativas"15.

Trata-se do conhecimento do não-saber que, para Kant, apenas é possível pela crítica da própria razão ${ }^{16}$, e que para Marion é um conhecimento que pertence ao âmbito dos fenómenos saturados, no sentido em que estamos em presença de algo que a partir do seu "poder de aparecer" excede o nosso "poder de conhecer", constituindo-se irredutível à categoria de objeto ${ }^{17}$. A iniciativa é dada ao fenómeno, invertendo o intento do eu em controlar a visibilidade, constituindo-se nessa reflexão da doação, a proximidade entre teologia e filosofia ${ }^{18}$.

\section{A REDUÇÃO AO FENÓMENO DA DOAÇÃO}

O autor apresenta a noção de doação como princípio último, mediante o reconhecimento do qual, a presença de cada coisa pode cumprir-se sem nenhuma

\footnotetext{
12 Ibid., 55.

13 Marion, Étan donné, 370.

14 Jean-Luc Marion, Certitudes negatives (Paris: Grasset et Fasquelle, 2010), 12-13.

15 Ibid., 17.

16 Immanuel Kant, Crítica da Razão Pura, A 758 (Lisboa:Fundação Calouste Gulbenkian,1989), 608 .

17 Marion, Certitudes negatives, 20.

18 Jean-Luc Marion, "Remarques sur l'utilité en théologie de la phénomenologie”, in José Cantó, José Maria Figueroa (eds.), Filosofia y Teologia en diálogo desde América Latina. Homenaje a Juan Carlos Scannone en su 80 cumpleaños (Córdoba: EDUCC, 2013), 540.
} 
condição ${ }^{19}$. Como vimos anteriormente, a fenomenologia tem como tarefa libertar a presença de todas as condições para receber o que se dá tal como se dá e, nesse sentido, a redução tem como objetivo purificar o fenómeno da aparência ou de tudo o que não se dá sem reservas, para o deixar aparecer como dado, desprovido de causa, de origem e de antecedente identificável ${ }^{20}$. Desta forma, Jean-Luc Marion defende que só a doação pode restabelecer uma filosofia primeira que dá iniciativa aos fenómenos mesmos, não fixando um princípio a priori nem a anterioridade de um eu transcendental ${ }^{21}$.

A epoché fenomenológica deixa de ser um ato reflexivo e teórico para se transformar em algo de âmbito anímico que entrega a iniciativa ao fenómeno. Como sublinha Paul Marinescu, se a hermenêutica heideggeriana trabalha a partir da ideia de um ver que já inclui uma estrutura de explicitação, a de Marion fundase no facto de experimentarmos acontecimentos que vemos sem nenhum tipo de compreensão prévia ${ }^{22}$. Nesse sentido, através da exploração de uma irrepresentabilidade traduzida pela noção de "fenómeno saturado" concorda com Paul Ricoeur que, mediante o recurso às mediações da poética e da narração, reconhece não ser possível uma fenomenologia pura do tempo.

A redução constitui-se, assim, como o olhar para aquilo que apenas é acessível pela fenomenologia, cuja reflexão é dada sobre o âmbito afetivo fundamental da vida. A disposição de quem escuta e é afetado pela aparição do fenómeno ganha primazia sobre a posição daquele que exerce operações de demonstração. Para Marion, ao contrário da metafísica que procura fundamentar a aparência para a conhecer e reconduzir à certeza, a fenomenologia tem como objetivo apenas mostrar, ou seja, deixar que a aparência apareça para ser recebida exatamente como se dá ${ }^{23}$, sem precisar de encontrar uma causa ou razão para esse dar-se do fenómeno.

Nesse sentido, o método fenomenológico é paradoxal, porque toma a iniciativa, por via da redução, para depois a perder, com o objetivo de alcançar as aparições das coisas na sua originalidade primigénia ou no estado nativo da sua manifestação incondicional a partir de si mesmo. A indubitabilidade a que deve chegar o método fenomenológico não é a da posse de objetos certos, produzidos de acordo com as condições a priori da consciência, mas sim aquela que provém

19 Marion, Réduction et donation, 7.

20 Jean-Luc Marion, De surcroit, 30.

21 Ibid., 56.

22 Paul Marinescu, "L'universalité et les "sans fin" de l'herméneutique: Jean-Luc Marion, lecteur de Ricoeur", in, Lectures de Jean-Luc Marion, ed. Christian Ciocan et Anca Vasilou (Paris: Cerf, 2016), 346.

23 Marion, Étan donné, 12-13. 
da aparição das coisas ${ }^{24}$. A redução de Marion, radicalizando a epoché da redução do mundo externo objetivo ao mundo interno subjetivo da vida mental do sujeito e da recondução às operações que sustêm os fenómenos, suspende as teorias pressupostas e as falsas realidades da atitude natural no mundo objetivo, para deixar que as vivências deixem aparecer o que se manifesta por $\mathrm{si}^{25}$.

Embora a iniciativa não pertença ao sujeito, a sua intervenção, pelas disposições afetivas e pela posição incondicionada da gratuidade em resposta ao chamamento do $\operatorname{ser}^{26}$, é indispensável para que se concretize a doação. Um chamamento que Marion diz ser ainda mais radical que o chamamento do "ser" de Heidegger e do "outro" de Levinas (redução existencial), porque é "chamamento puro", fruto de uma redução radical e essencial em que o que se dá apenas se dá àquele que se entrega ${ }^{27}$.

Como salienta Juan Carlos Scannone ${ }^{28}$, para Marion o interlocutor do chamamento, que é o interpelado, é caracterizado pelas seguintes dimensões: a) renuncia à subjetividade absoluta e reconhece-se como derivado de uma relação anterior (convocatória); b) experimenta a surpresa que se apodera dele a partir de uma instância alheia a ele, fazendo com que o chamamento se traduza por um acontecimento que não pode ser antecipado nem compreendido (surpresa); c) o interpelado não é dissolvido na indistinção, mas na elaboração da resposta à chamada do "aí", o "a mim" reconhece-se a si mesmo (Identidade); d) o interpelado é exposto a uma pergunta de facto antes de qualquer pergunta de direito sobre o estatuto da sua subjetividade, no reconhecimento de uma anterioridade da facticidade absolutamente outra que convoca em relação à teoria do sujeito convocado (facticidade). Considera Marion que no plano fenomenológico a instância reivindicadora do interpelado não deve ser chamada de Deus, porque o adonado se identifica como convocado antes de poder reconhecer a sua subjetividade e quem o convocou: apenas a indeterminação da instância reivindicadora permite a reivindicação, pois se não fosse surpresa, não provocaria nenhuma interpelação nem suscitaria a resposta ${ }^{29}$.

À redução transcendental de Husserl (redução ao $E u$ constituinte), que proporciona a constituição de objetos excluindo da doação aquilo que não se pode

24 Ibid., 14.

25 Ibid., 15-16.

26 Marion, Réduction et donation, 283.

27 Ibid., 296.

28 Juan Carlos Scannone, "Outro como si mesmo. El llamado y el responsório según Jean-Luc Marion", in Jean-Luc Marion: limites y possibilidades de la Filosofia y de la Teologia, ed. Jorge Luis Roggero (Buenos Aires: SB Editorial, 2017), 47.

29 Marion, Réduction et donation, 300-301. 
objetivar (horizonte da objetividade), e à redução existencial ou ontológica de Heidegger (redução ao Dasein) em que o dado dá-se no horizonte de tempo de acordo com o ser mesmo como fenómeno originário e último, excluindo da doação do que não é (horizonte da enticidade), Jean-Luc Marion acrescenta um terceiro nível de redução que provem da pura forma do chamamento (redução ao interpelado) e que proporciona o dom em si mesmo, definido como o "entregarse à reivindicação do chamamento" (horizonte da doação) ${ }^{30}$. Neste âmbito, o único horizonte é o do chamamento absolutamente incondicionado e da resposta sem qualquer restrição, capaz de superar os limites do objeto e do ser, porque precede qualquer outra especificação ${ }^{31}$.

Mas então, como observa Claude Romano, quem é o operador da redução? É o sujeito, enquanto interpelado, ou é a própria doação, procedendo da manifestação do fenómeno saturado? Se não for o sujeito, a redução perde a característica de método, indispensável à prática fenomenológica? ${ }^{32}$ Este autor considera que Marion deveria apresentar a sua proposta de redução, mais no âmbito de um modo de manifestação e não no sentido de uma operação metodológica. Em resposta a esta objeção, Marion não abdica da redução, que permite a passagem da aparência do aparecer para o aparecer dos fenómenos enquanto tais ${ }^{33}$. E acrescenta que em qualquer redução dá-se uma transformação do sujeito, que no caso de Husserl significa uma redução à imanência de si mesmo e no caso de Heidegger significa uma transformação do Dasein, que passa a entender-se como transcendente aos entes intramundanos. Assim, a redução reduz primeiro a quem a opera e, no caso de Marion, significa a redução do sujeito a interpelado, implicando uma transferência do seu "si" ao fenómeno, de maneira a ater-se ao modo em que o fenómeno se mostra.

A radicalização da redução permite identificar o fenómeno não redutível de Deus, como o que vem à ideia sem pressupor nada e do qual não podemos escapar, e o fenómeno não redutível da operação mesma de redução ${ }^{34}$. $\mathrm{O}$ "eu transcendental" de Kant e de Husserl, que constitui objetos, é o resultado e não a origem da redução, mas para Marion a redução não pode ser concebida sob esse modelo da objetivação, que impede a redução à doação ${ }^{35}$. Mas a redução reduz simultaneamente o sujeito e o objeto, pelo que o sujeito transfigura-se em ministro da doação, que, longe de construir objetos, se recebe na sua modalidade de

$30 \quad$ Ibid., 305.

31 Marion, Étan donné,59.

32 Claude Romano, "Remarques sur la méthode phénoménologique dans Étant donné de Jean-Luc Marion", Annales de philosophie, 21 (2000), 13.

33 Marion, De surcroit, 57.

34 Marion, Figures de phénoménologie, 188.

35 Jean-Luc Marion, Reprise du donné (Paris: PUF, 2016), 43. 
interpelado ou acolhedor do dado ${ }^{36}$. Considera Jorge Roggero, que Marion procura afastar-se do Husserl convencional cartesiano, que entende a redução como operação de objetivação, e aproximar-se do novo Husserl que dá outro sentido à transcendentalidade e à constituição, reconhecendo que no processo da redução há uma correlação entre o "quê" e o "quem", porque o objeto só é reduzido ao dado enquanto o sujeito é reduzido a "adonado" nessa doação ${ }^{37}$. Neste plano se entende a redução do sujeito ao seu próprio eu imanente, que significa a redução do eu transcendental do corpo à auto-afeção da carne ${ }^{38}$, numa conveniência entre o dado e o "adonado".

Toda a redução implica o método da epoché com a retenção e suspensão de tudo o que ainda não se encontra absolutamente dado ${ }^{39}$. Mas por outro lado, na sua obra sobre o pintor Courbet, Marion parece admitir uma epoché sem redução, explicando que a verdadeira criação do artista não nasce da sua vontade, mas da neutralização do seu ego por via da epoché sem redução, o que permite entregarse ao acontecer imprevisível da obra ${ }^{40}$. Na sua obra L'homme blessé (1844-1845), exposta no Museu d'Orsay, o pintor apresenta esta noção da morte do autor como sujeito dominante e organizador da pintura. Courbet não é autor das suas obras, mas apenas o testemunho que regista o que advém enquanto tal de forma imprevista num pensamento que não se domina, mas simplesmente deixa aparecer. Nesta atitude ascética, paradoxalmente ativa e passiva, a redução apenas tem a função de deixar que a manifestação se manifeste ${ }^{41}$.

\section{O EU, ENQUANTO INTERPELADO PELO CHAMAMENTO DOS FENÓMENOS}

Assim, num exercício de ampliação da fenomenalidade, o pensador francês liberta a possibilidade de aparição dos fenómenos do condicionamento provocado pelo conhecimento que o sujeito exerce sobre eles. Naquilo que se pode chamar de uma ascese ao mesmo tempo ativa e passiva, o sujeito interpelado responde ao chamamento dos fenómenos da realidade, num processo em que a indeterminação da doação se revela como a única determinação possível. Esta posição recetiva do sujeito à iniciativa do outro resulta da capacidade em assumir um estado de ânimo

\footnotetext{
36 Ibid., 44.

37 Roggero, Hermenéutica del amor, 271.

38 Marion, Reprise du donné, 47.

39 Ibid., 55.

40 Jean-Luc Marion, Coubert ou la peinture à l'oeil (Paris: Flammarion, 2014), 95.

41 Marion, Étan donné, 15-16.
} 
amoroso, à semelhança do amante que na iniciativa de amar perde toda a iniciativa e se abandona ao amado deixando-se afetar no seu mais profundo íntimo.

Propondo repensar a fenomenologia num sentido que vá para além do sujeito, Jean-Luc Marion segue a inversão da intencionalidade realizada por Levinas e situa a redução, não no plano do cogito, mas num fundamento anímico. Com Heidegger, a intencionalidade passa a ser situada no domínio pré-teorético em que não há distinção entre sujeito e objeto nem polarização entre a esfera psíquica e a esfera física. O experienciar-se do sujeito a si mesmo, no mundo circundante, não é uma reflexão teorética nem uma perceção interna, mas é uma experiência do mundo de si mesmo ${ }^{42}$. Neste sentido, para Marion, o sujeito não produz nem possui o fenómeno, mas beneficia dele. O sujeito é afetado pela intuição que precede o pensamento. A impressão originária que dá acesso à temporalidade não se dá numa unidade sintética, nem numa constituição transcendental do objeto, mas advém do abandono da posição de representação por parte do eu e da adoção de uma atitude recetiva que se constitui como o único a priori da doação ${ }^{43}$.

Através de um olhar curioso que se submeta às exigências da figura que pretende ver, o fenómeno passa do informe à aparição afetando o eu comprometido (anamorfosis) ${ }^{44}$. Só depois da chegada do fenómeno, na sua facticidade contingente, poderá ser conhecido ${ }^{45}$. $\mathrm{O}$ fenómeno mostra-se porque se dá a partir de si mesmo e não porque o eu o desvela. Se para a metafísica os entes são efeito ou causa e tudo o que advém tem a sua causa, para a fenomenologia o acontecimento do fenómeno melhor se mostra e se advém inteligível se não estiver no âmbito da causalidade. Ora, esta noção implica uma pergunta imediata: de que forma é concebível o divino no contexto de uma manifestação não causada sem se cair na imanência indistinta do panteísmo?

Contra a evidência metafísica cartesiana da causa e do efeito como realidades estáveis e permanentes, Marion considera que do ponto de vista fenomenológico o efeito dá-se em modo de surgimento e tem anterioridade em relação à causa, no modo presente do aparecer, surgindo a causa como um efeito desse efeito. Todos os acontecimentos são absolutamente individualizados, únicos e irrepetíveis, sem antecedentes e sem retorno. Os fenómenos saturados ou dados, que não são objetos e que se manifestam a partir de si, aparecem ao sujeito enquanto adonado. Mostram-se de imediato tal como são ao sentimento do eu recetor, antes da sua conceptualização pelo ego constituinte. Desta maneira a doação realizada na

\footnotetext{
42 Heidegger, Gesamtausgabe, 60, 13.

43 Marion, Étan donné, 384.

44 Ibid., 205.

45 Ibid., 207.
} 
recetividade do eu transforma-se em manifestação, permitindo que aquilo que se dá também se mostre. Se o impacto do fenómeno corresponde a um chamamento, deparamo-nos com o eu "adonado" 46 .

O chamamento da realidade essencial fenoménica está sempre ali, já dado originariamente numa linguagem inaudita, mas só se mostra na resposta do $\mathrm{Eu}$ que se entrega integralmente, através de uma palavra que exige a redução do plano categorial e objetivo para o plano antepredicativo, comovido e atemático da doação e cuja comunicação implica a superação do discurso predicativo lógicoanalítico para um discurso analógico transpredicativo de feição poética. Este chamamento não é concebido como proveniente de uma instância transcendente que atua como princípio metafísico, porque mantém o anonimato. Assim, não sendo concebida como um princípio transcendente, o eu interpelado não se apresenta com carácter derivado e a sua resposta dá-se no plano da redução à imanência pura da doação. O apelante pode ser identificado com Deus (revelação), Ser (acontecimento) ou Vida (auto-afeção), mas, Marion considera que isso significa reintroduzir um processo metafísico, insistindo que o chamamento é anónimo e que o adonado responde a partir da imanência da doação, numa consciência de interpelação que é anterior à consciência da subjetividade ${ }^{47}$.

No entanto Marion, admite a possibilidade de uma interpretação, feita $a$ posteriori, no campo metafísico, dando a última palavra à via teológico-filosófica do $a_{0} r^{48}$. Ao contrário do que afirma Jorge Roggero, admitir que o chamamento provém de Deus não significa abandonar o campo da filosofia ${ }^{49}$, mas sim percorrê-lo até às últimas consequências. Significa, no entanto, abandonar o campo da fenomenologia, tal como é apresentada por Marion, que faz corresponder o chamamento a uma indeterminação e que considera ser esse o único modo de surpreender o adonado que responde, porque ignora quem chama e ignora o porquê desse chamamento. Se perante um objeto, a vontade deseja o que o entendimento vê com evidência e pode vê-los sem os querer, perante os fenómenos saturados, que não podem ser vistos, é necessário tomar a decisão de os querer e de os receber sem os ter visto, ou seja, sem os compreender e conceber a priori ${ }^{50}$.

Os fenómenos saturados apenas mostram o dado de forma inadequada e desse modo, o adonado recebe o excesso de doação sem o objetivar: é a decisão de os querer ver que torna possível a sua visão e racionalidade. O processo racional da

46 Ibid., $427 ; 436$.

47 Ibid., 488.

48 Marion, La rigueur des choses, 189.

49 Roggero, Hermenéutica del amor, 308.

50 Marion, Étan donné, 496. 
visibilidade dos fenómenos é inaugurado pela decisão da vontade, estando precedido por uma obscuridade pré-fenomenológica e pré-racional em que o eu apenas se pode apoiar na imanência da doação mesma. Não há uma distância lógica e cronológica entre o chamamento e a resposta, pelo que esta ocorre sob o modo indeterminado e silencioso no plano da imanência: a transcendência implicada no processo do chamamento, que está sempre aí, é mais íntima que eu mesmo. Em diálogo com Santo Agostinho, Marion aponta para uma instância que não está em mim nem fora de mim, traduzida pela noção de "si mesmo", e que corresponde ao ego amans anterior ao ego cogito e que nos expõe a uma transcendência divina que na sua alteridade absoluta devém constitutiva da nossa mesmidade ${ }^{51}$.

Em que termos se pode abordar a noção de transcendência a partir de uma perspetiva fenomenológica e não metafísica? A distinção entre transcendência e imanência é reconfigurada pelo uso da expressão "além" e "Outro", que em Marion se identificam com a noção de "amor". No "amor", uma transcendência se inscreve no mais imanente da imanência, na constituição mesma da minha subjetividade. Nas palavras de Juan Carlos Scannone, é o Outro como Mim em mim quem Se me dá e me dá a mim pela ipseidade ${ }^{52}$. Considera Marion que o ego não acede a si mesmo pela auto-afeção, como em Henry, nem como outro, em Ricoeur, mas devém a si mesmo por outro, isto é, por meio de um dom ${ }^{53}$. A alteridade ou a outridade que nos habita e constitui a nossa mesmidade identificase com Deus em Santo Agostinho e em Marion, mas na filosofia contemporânea separada da teologia, pode identificar-se simplesmente com a alteridade humana ou com a vida.

\section{A RELAÇÃO ENTRE A FENOMENOLOGIA E A TEOLOGIA}

Em diálogo com Pascal que concebe a onto-teologia de Descartes a partir da visão superior da caridade, Jean-Luc Marion reconhece a metafísica como vã a partir do olhar da caridade ${ }^{54}$. Na lógica do amor, filosofia e teologia não se distinguem pelos seus conteúdos, mas pelas vias metodológicas: a filosofia considera o objeto como possível e a teologia como efetivo, não propondo

51 Jean-Luc Marion, Au lieu de soi, l'aproche de Saint Augustin (Paris: PUF, 2008), 144.

52 Juan Carlos Scannone, "Outro como si mesmo. El llamado y el responsório según Jean-Luc Marion", in Jean-Luc Marion: limites y possibilidades de la Filosofia y de la Teologia, ed. Jorge Luis Roggero (Buenos Aires: SB Editorial, 2017), 55.

53 Marion, Au lieu de soi, l'aproche de Saint Augustin, 383.

54 Jean-Luc Marion, Sur le prisme métaphysique de Descartes. Constitution et limites de l'ontothé-logie cartésienne (Paris, Puf, 1986), 377. 
nenhuma questão para resolver, mas limitando-se a desenvolver o já adquirido. Contra a separação esquizofrénica entre filosofia e teologia, proposta por Maurice Blondel e por Paul Ricoeur, e não totalmente superada por Levinas, Marion e Henry, o filósofo do Instituto Católico de Paris, Emmanuel Falque, propõe um verdadeiro encontro entre estes domínios ultrapassando o carácter literal da revelação e atendendo à hermenêutica do depósito da tradição ${ }^{55}$. À semelhança dos teólogos que se alimentam da filosofia, também os filósofos podem recorrer à teologia sem separar o humano do divino e sem cair numa interpretação equivocada das três ordens de Pascal que conduz à errada contraposição entre a apologética da razão teológica e a apologética da razão filosófica, pelo "salto" da fé (fideísmo) ou da filosofia pura (racionalismo) ${ }^{56}$.

Não é possível aceder à excedência ou à saturação através do modelo de "salto" ou de "umbral" sem passar em primeiro lugar pela finitude da condição humana, pelo que a solução é um exercício conjunto da filosofia e da teologia, em que a experiência da finitude humana não atua como um limite, mas como um ponto de partida a partir do qual de avança para uma metamorfose e uma passagem para o campo teológico: do corpo para a encarnação, da angústia para o Getsemaní, do eros para a eucaristia, do nascimento para a ressurreição, do erro para o pecado, da infância para o reino ${ }^{57}$. A teologia não se pode realizar de modo autêntico se não partir da finitude como ponto de partida, porque esta é desejada por Deus: não somos pura natureza, mas somos criaturas de Deus ${ }^{58}$. A filosofia é transformada em contacto com a teologia, na medida em que recebe a força do mistério da ressurreição $0^{59}$.

Não há dúvida que Marion é católico e que o sentido último da sua filosofia se encontra nas reflexões teológicas, mas ao contrário de Emmanuel Falque, que procura uma conciliação com a metafísica, opta por uma via de superação da metafísica, abrindo-se à teologia apenas pela ordem da caridade, naquilo a que podemos chamar uma certa cedência à cisão kantiana entre razão teórica e razão prática. É nesse âmbito que recusa a noção de uma filosofia cristã, embora partilhe com Husserl a ideia de que uma filosofia autónoma, como aquela que fazia Aristóteles, chega necessariamente a uma teleologia e a uma teologia filosófica, como caminho não confessional para Deus ${ }^{60}$. Para Husserl, a via fenomenológica deve permanecer num ateísmo ou agnosticismo metodológico, aí residindo a sua

55 Emmanuel Falque, Passer le Rubicon. Philosophie et Théologie: essai sur les fronteires (Bruxelles: Lessius, 2013), 179.

56 Ibid., 183.

57 Ibid., 152.

58 Ibid., 186.

59 Ibid., 166.

60 Husserl, Husserliana, XLII, 259. 
legitimidade filosófica, posição que é rejeitada por Falque, para quem a diferença entre estas duas áreas é apenas metodológica e para quem se pode identificar uma certa influência implícita da teologia no desenvolvimento de certas categorias fenomenológicas de Marion.

A fenomenologia da doação, embora pretenda o acesso aos fenómenos saturados, tem como ponto de partida a finitude do ser humano e, por isso, reconhece que nem todo o dado pode mostrar-se, cabendo à condição finita do homem a passagem hermenêutica da doação à fenomenalização. O que interessa a esta filosofia é a região da não objetivação onde sobrevivem as realidades não previsíveis dos acontecimentos e, por isso, como salienta Jorge Luis Roggero, não se postula apenas como uma fenomenologia da religião que procura dar acesso à manifestação gloriosa de Deus sem passar pela sua manifestação na cruz, mas atende ao acontecimento que se dá no rosto do outro e em todo o fenómeno mais banal do quotidiano ${ }^{61}$. O carácter excessivo e extraordinário não se aplica apenas ao divino, mas também à finitude e debilidade do rosto humano e de todo o fenómeno desde que não estejam reduzidos a operações objetivantes que impedem o reconhecimento desta finitude e debilidade.

A destituição da metafísica proposta por Pascal implica um salto para a teologia, mas a destituição proposta por Marion segue uma via distinta, procurando a lógica do amor a partir da filosofia, passando da lógica do objeto para a lógica do acontecimento, como são os casos da história ou da carne. A passagem para a lógica do coração ou do amor (acontecimento) não implica anular a lógica do espírito. Quando se perde a fé, perde-se na razão, no sentido em que se acredita que esta é incapaz de compreender o âmbito mais decisivo daquilo que experimentamos em nossa vida: é o que acontece quando se admite uma área que permanece incompreensível e irracional e se a abandona ao domínio da crença e da opinião ${ }^{62}$.

A verdade é que se não se perde a fé por um excesso de prática racional, mas perde-se racionalidade ao excluir dela o domínio da fé e da revelação que, não pertencendo à inteligibilidade lógico-analítica da objetivação, acrescenta a inteligibilidade analógico-mistérica do que precede e transcendente a objetivação. A definição restritiva moderna da natureza da razão e das suas capacidades é um dogma que deve ser superado pela confiança no poder e na legitimidade da própria racionalidade $^{63}$. O que está em causa na relação entre fé e razão não é um debate apologético entre religião e filosofia, mas é o próprio alcance da racionalidade

61 Roggero, Hermenéutica del amor, 443.

62 Jean-Luc Marion, Le coire pour le voir (Paris: Cmmunio Parole et Silence, 2010), 9.

63 Ibid., 10. 
filosófica. Nesse sentido propõe uma nova relação entre fé e razão que já não é a onto-teológica da metafísica tradicional que se desenvolve sob duas formas: a) a fé, apenas quando a razão já não pode aceder ao que a fé define de verdade; b) a fé aumenta se for apoiada na razão. A modalidade proposta por Marion é a de regresso à via augustiniana por meio da fenomenologia, no reconhecimento de que a fé é condição de fenomenalização dos fenómenos mais decisivos: só acedemos à ordem do coração e da santidade se dispusermos da significação apropriada que é a caridade em si mesma, mas só dispomos dela se acedermos a ela tal como se dá, ou seja, pela fé. Para ver é necessário crer, mas essa crença é uma obra da racionalidade na sua expressão máxima, apelidada por Nietzsche de "grande razão"64.

Defende Roggero que na categoria de "fenómeno saturado" é evidente a correlação entre filosofia e teologia na obra de Marion, permitindo até a sua aplicação na investigação de objetos teológicos como são a oração, a santidade, a eucaristia e o sacramento ${ }^{65}$. Mas mais uma vez, este discurso, já pressupõe ele mesmo uma separação artificial entre estes dois domínios. A questão não está no facto secundário de a filosofia se apropriar de ideias teológicas para as transformar de acordo com os seus hábitos, como considera Roggero ${ }^{66}$, mas está no facto de a filosofia se reduzir ao plano objetivo dos fenómenos do Mundo ou de se ampliar à realidade metafísica dos mistérios divinos (teologia filosófica) que inclui os dados da revelação e da graça, isto é, inclui a imanência da experiência vital e a transcendência da vida ultraterrena.

\section{A MANIFESTAÇÃO DE DEUS NA EVIDÊNCIA DA SUA AUSÊNCIA E DO DOM AMOROSO DA SUA PRESENÇA VELADA}

A solução não poderá passar exclusivamente pela proposta fideísta luterana do Deus absconditus, assumida pelo jovem Heidegger, assente, não no poder da racionalidade, mas no paradoxo da crucificação na fragilidade da cruz. Não se fundamentará exclusivamente no acontecimento do Deus que apenas se revela indiretamente e paradoxalmente no sofrimento de Cristo crucificado, mistério que é escândalo e loucura. A teologia crucis de Lutero, assumida pela filosofia de Heidegger, implica a noção da misteriosa mostração de um Deus que se revela sob o modo de ocultação e aponta para esse encobrimento também na mostração da vida fáctica, sob a modalidade de "não presença". O Deus absconditus mostra-

$64 \quad$ Ibid., 13.

65 Roggero, Hermenéutica del amor, 451.

66 Ibid. 
se, como tal, no seu mostrar-se, aí na cruz, sem representação indireta, mas sob a modalidade de encobrimento ${ }^{67}$.

Para aceder a este fenómeno é preciso destruir o conhecimento dos sábios nas suas construções conceptuais a priori, que impedem o fenómeno de se mostrar a si mesmo enquanto tal, e é necessário assumir uma atitude de humilde entrega ao acontecer do fenómeno. Desta maneira, por princípio, a filosofia deve ser existencialmente ateia ${ }^{68}$, tal como a teologia crucis luterana que parte da ausência de Deus sem pressupor o alcançado, respondendo à necessidade filosófica e religiosa de questionamento que assume a perplexidade da existência finita como o único ponto de partida possível.

Sob a influência de teólogos como Henri de Lubac, Jean Daniélou e Hans Urs von Balthasar, Jean-Luc Marion dialoga com a patrística de Gregório de Nissa e São Máximo Confessor e participa no movimento da nouvelle théologie que funda a coleção Sources Chrétiennes como resposta à neo-escolástica que seguia a metafísica clássica. No pressuposto de que a metafísica fazia a separação entre filosofia e teologia, Marion opta por Santo Agostinho, para quem essa distinção não existia ${ }^{69}$, e desenvolve a noção da revelação como dom, no reconhecimento de que na abordagem de qualquer questão não se deve partir dos nossos preconceitos, mas sim da presença da coisa mesma, tal como verifica com os acontecimentos da encarnação e da ressurreição que impõem a sua própria medida e não estão sujeitos à nossa ${ }^{70}$.

A noção de "paradoxo", usada por Henri de Lubac como categoria para reconhecimento do mistério, é transposta para a construção da noção de "fenómeno saturado". Não se dá o abandono da razão, mas sim a conviçcão de que quanto mais há de mistério mais há de razão ${ }^{71}$. A dimensão analógica e paradoxal está presente na realidade antes de estar no pensamento e, ao contrário da dialética, não se supera, sendo a simultaneidade do um e do outro, escapando ao domínio das leis lógicas da silogística aristotélica. Esta lógica paradoxal não desautoriza a lógica do objeto, mas inaugura o novo âmbito em que se dão os fenómenos fundamentais que dão sentido à nossa existência. Para Marion, em diálogo com Lubac e com Balthasar, a Encarnação é o paradoxo supremo e a Revelação não tem condições de possibilidade ${ }^{72}$, constituindo-se a ausência e a

67 Heidegger, Gesamtausgabe, 63, 67.

68 Heidegger, Gesamtausgabe, 61, 197.

69 Marion, Au lieu de soi, l'aproche de Saint Augustin, 27.

70 Jean-Luc Marion, "Ce mystère qui juge celui qui le juge”, Résurrection, 32 (1970), 54-78.

71 Henri de Lubac, Corpus Mysticum, L'Eucharistie et l'Eglise au moyen age, (Paris: Aubier, 1948), 260.

72 Marion, Étan donné, 329. 
distância divina como formas de manifestação e da evidência de Deus ${ }^{73}$. A distância divina entre pai e filho traduz-se na distância cristã entre Deus e homem ${ }^{74}$ que aponta para um modo de manifestação sob a forma de velamento, pois não pode ser conceptualizado e definido ${ }^{75}$. No entanto, o teólogo Hans Urs von Balthasar critica Jean-Luc Marion por defender um "Deus sem ser", considerando que o amor gratuito não é prévio ao ser, mas seu ato supremo aí naufragando a sua compreensão ${ }^{76}$.

O pensador francês fundamenta o seu sistema na noção de que o fenómeno se mostra a partir de si mesmo, como dom, à semelhança dos acontecimentos da revelação de Cristo e da sua presença na Eucaristia que também são concebidos como dons ${ }^{77}$. A partir das experiências do perdão e do sacrifício é possível desenvolver uma hermenêutica do dom e uma hermenêutica do amor que nos permite passar da interpretação objetivante para a interpretação do acontecimento. $\mathrm{O}$ autor desenvolve uma fenomenologia da compreensão erótica que analisa o fenómeno do amor na sua doação positiva. A filosofia deve ser uma sabedoria, deve procurar as palavras para dizer o amor e os conceitos para o pensar, abordando-o pela fenomenologia da doação, partilhando com Platão a noção de que cada dimensão da alma faz a experiência do prazer e a compreensão do belo. Se a alma racional (lógos) não for orientada pelo amor, transforma-se em mero cálculo: é preciso amar para compreender ${ }^{78}$. É o amor que nos dá acesso à transcendência do outro (alteridade) e nos permite a compreensão mais importante para o sentido da nossa existência. O amante mais antigo é identificado com Deus, único garante da eternidade ${ }^{79}$.

A fenomenologia do amor tem como princípio a noção de que Deus é amor (1 Jo 4, 8) e que, por distinção com as noções analógicas de ser, bem, belo e verdade, que encerram uma semelhança com a criatura que preserva uma dissemelhança ainda maior, a noção de amor não é analógica, constituindo o mesmo para Deus e para o ser humano (univocidade) ${ }^{80}$. No pressuposto de que apenas Deus nos dá o amar, o autor considera que não há separação entre o amor de Deus e o amor que damos a qualquer outra criatura, partilhando com Von

73 Jean-Luc Marion, L'idole et la distance. Cinq études (Paris: Grasset, 1977), 123.

74 Hans Urs von Balthasar, Theodramatik. V. Das Endspiel, (Einsiedeln: Johannes Verlag, 1983), 108.

75 Marion, L'idole et la distance, 256.

76 Hans Urs von Balthasar, Theologik II Wahrheit Gottes (Einsiedeln: Johannes Verlag, 1985), 163.

77 J ean-Luc Marion, “Le présent et le don”, Communio, II, 6 (novembre 1977), 50-70.

78 Jean-Luc Marion, Le phénomène érotique (Paris: Grasset, 2003), 12.

79 Ibid., 341.

80 Ibid. 
Balthasar a noção de que em sua realidade última o amor não é conhecido por mais nada que não seja pelo próprio amor. $\mathrm{O}$ acesso à revelação de Deus está dado pela graça do amor que apenas se pode corresponder com o amor (univocidade): só porque a palavra já foi compreendida como amor é possível que se siga a resposta do $a_{0}{ }^{81}$. $\mathrm{O}$ amor divino é a medida do amor humano e o sentido da nossa existência só é possível na experiência do amor, porque este é concebido como o conhecimento por excelência, não o conhecimento do objeto para o que basta a evidência do entendimento, mas o conhecimento do outro enquanto tal ${ }^{82}$. A caridade não é irracional ou apenas afetiva, porque promove um tipo de conhecimento de uma ordem não objetiva, distinta da racionalidade lógicoanalítica do nosso conhecimento comum ${ }^{83}$.

Podemos conhecer o mundo na sua extensão material (física, geologia), na sua realidade espiritual (ciências, lógica) e também na sua dimensão de amor e graça (caridade) que oferece uma heurística que permite aceder os fenómenos mais decisivos. A fé no amor não tem nada de irracional permitindo conhecer, não por uma racionalidade de posse e domínio, mas por uma racionalidade de respeito, cuidado e acolhimento, que dá acesso a fenómenos novos e revela o mundo em todas as suas dimensões, incluindo a dimensão da manifestação divina ${ }^{84}$.

\section{CONCLUSÃO: O MOTIVO TEOLÓGICO DA FENOMENOLOGIA DA DOAÇÃO QUE SE ABRE À POSSIBILIDADE EXCESSIVA DA AUSÊNCIA QUE SE PRESENTIFICA DE FORMA NÃO OBJETIVA}

A nouvelle phénoménologie de Jean-Luc Marion é criticada por uns autores pelo facto de conservar uma separação fideísta ou pietista, à maneira kantiana e husserliana, entre filosofia e teologia, mas também é criticada por outros, como por exemplo Dominique Janicaud, pelo problema contrário da ausência de uma separação entre teologia e fenomenologia e da consequente falta de rigor metodológico ${ }^{85}$.

No entender deste autor, o projeto de Marion, apresentado em Dieu sans l'être, consiste em dar continuidade ao projeto de Heidegger sobre a possibilidade

81 Hans Urs von Balthasar, Só o Amor é digno de Fé (Lisboa: Assírio \& Alvim, 2008),77. Cf. Ignacio Verdú, “Amor y metafísica. Una reflexión acerca de la filosofía primera”, Cauriensia 14 (2019): 117-130.

82 Jean-Luc Marion, "La connaissance de la charité", Communio, XIX, 6 (1994), 34.

83 Ibid., 42.

84 Marion, Sur le prisme métaphysique de Descartes, 333.

85 Dominique Janicaud, "Le tournant théologique de la phénoménologie française", in $\mathrm{La}$ phénoménologie dans tous ses états, ed. Dominique Janicaud (Paris: Gallimard, 2009), 101-102. 
de uma teologia sem ontologia. No mesmo sentido, o projeto apresentado em Réduction et donation consiste numa fenomenologia negativa ${ }^{86}$. Num e noutro caso, parece haver uma ilegítima intromissão no processo fenomenológico de princípios teológicos superadores da metafísica.

No mesmo sentido, François Laruelle, defende que o projeto de Marion consiste na tentativa de conciliar as propostas contrárias de Husserl e Heidegger e também de Levinas e de Henry, ou seja, consiste na procura de compatibilizar "imanência", "receção" e "afeção" com "transcendência", "dado" e "recebido", num processo que esconde os motivos teológicos que atuam de forma ilegítima na filosofia ${ }^{87}$.

Mas, mais significativa que estas críticas é a observação de Jocelyn Benoist sobre a teologia negativa da obra Lídole et la distance, que, no seu entender, deixa o divino numa extrema pobreza de determinação ${ }^{88}$. Por outro lado, para este pensador, a doação não pode deixar de estar relacionada com a intuição sensível, tornando-se difícil aplicar nesse âmbito o conceito de Deus, pois, como pode o não-sensível dar-se no sensível ${ }^{89}$ ? Para além do mais, considera também que a transcendência em Marion não se apresenta como objeto de uma crença, mas como uma evidência filosófica, estando relacionada como a noção fenomenológica husserliana da evidência do ver, levantando problemas perante aqueles que não conseguem ver o divino.

A esta última questão responde Marion que o facto de alguém não ver ou não compreender, não desvaloriza o facto mesmo de se ver e compreender, mas sim a quem não vê ou não compreende, pelo que a reivindicação da cegueira não pode constituir um argumento: o facto de não se ver não prova que não há nada para ver $^{90}$. Mas só é possível aceder a essa visão pela lógica do amor, na sua abertura cognitiva a novas significações ocultas ao conhecimento objetivo comum.

Mas o diálogo entre fenomenologia e teologia também é merecedor de apreço dos críticos que não cedem à perspetiva moderna kantiana, de origem pietista $\mathrm{e}$ fideísta, da dupla verdade e da cisão entre ontologia e teologia. Inserindo-o na família teológica de Levinas, Henry, Chrétien, Ricoeur e Derrida, o pensador Pascale Tabet defende que Jean-Luc Marion aborda a questão de Deus a partir de um marco fenomenológico em relação com a metafísica, num processo de

86 Ibid., 101.

87 François Laruelle, “L'appel et le phénomène”, Revue de Métaphysique et Morale 96, 1 (1991): $32-37$.

88 Jocelyn Benoist, "Le "tournant théologique"”, in Jocelyn Benoist, L'idée de phénoménologie (Paris: Beauchese, 2001), 86.

89 Ibid., 95.

90 Jean Luc-Marion, Le visible et le révélé (Paris: Cerf, 2005), 152. 
"fenomenalização da teologia" em que as escrituras são lidas sob a modalidade do possível e não do efetivo ${ }^{91}$.

Esta posição é evidente na obra Étant donné e justificada com mais profundidade na obra Givennes ad Revelation, ao afastar-se da posição filosóficoteológica tradicional medieval, que incidia nas provas da existência de Deus e na descrição dos seus atributos essenciais, para assumir a perspetiva epistemológica heideggeriana da inadequação entre o pensar e o ser, segundo a qual, a intenção de Deus com a revelação não é dar-se a conhecer no sentido da objetividade mundana e do desvelamento de uma coisa, mas sim tornar-se reconhecível pela comunicação amorosa de si mesmo, permitindo que os homens entrem em comunhão com Ele na correspondência desse amor ${ }^{92}$.

Em diálogo com Levinas, para quem a relação com o rosto do outro não se dá no sentido do conhecimento de um objeto, considera que a revelação divina não se situa no plano da explicação lógico-analítica de uma verdade ${ }^{93}$, porque opera com uma lógica diferente: nem mítica nem conceptual, mas mistérica, no sentido analógico e paradoxal que nos permite descrever uma experiência que não é objetivável: ${ }^{94}$ participação simultaneamente semelhante e dissemelhante do homem no ser, beleza, bondade e verdade de Deus e união, não analógica, no seu amor.

Também Carlos Enrique Restrepo defende o diálogo proposto entre filosofia e teologia e critica o uso do termo tournant que dilui de forma superficial aquilo que deve ser um genuíno acontecimento filosófico ${ }^{95}$, antecipando o que outros autores vão descrever como uma viragem, não teológica, mas uma viragem que torna viável uma fenomenologia que abre a possibilidade à ausência. Quando pressupomos que a fenomenologia apenas pode dar conta de presenças, então, não apenas Deus, mas também a ipseidade e a alteridade acabam excluídas, pois ninguém pode ser totalmente presente a si mesmo. Dessa maneira, considera Stéphane Vinolo que Marion procura ampliar o modelo da fenomenalidade à possibilidade de apresentar ausências ${ }^{96}$. Acontece, no entanto, que por via da

91 Pascale Tabet, Amour et donation chez Jean-Luc Marion. Une phénoménologie de l'excès (Paris: L'Harmattan, 2017), 257, 278.

92 Jean Luc-Marion, Givennes ad Revelation (Oxford: Oxford University Press, 2016), 27.

93 Ibid., 34.

94 Ibid., 56.

95 Carlos Henrique Restrepo, “El 'giro teológico' de la fenomenologia. Introducción al debate”, Pensamiento y Cultura 13, 2 (2010), 117.

96 Stéphane Vinolo, “Jean-Luc Marion: escribir la ausência. El 'giro teológico' como porvenir de la filosofia”, Escritos 20, 45 (2012), 291. 
hermenêutica do amor, Marion vai mais longe e inscreve o amor como a instância em que a ausência de faz presente na doação de si mesma.

Neste mesmo sentido, Roberto Walton defende que não se pode falar de "viragem teológica", porque o problema de Deus esteve no centro da fenomenologia desde o seu início em Husserl, nomeadamente através da questão da teleologia e da impossibilidade do mundo se justificar a si mesmo, exigindo a abertura para o plano metafísico de um ser fundamento que excede a evidência fenomenológica, pelo que, em vez de viragem, deve-se falar de retorno às origens ${ }^{97}$.

Assim, devemos concluir que o motivo que anima a fenomenologia da doação de Jean-Luc Marion é teológico e no entender de Emmanuel Falque não é possível fazer a experiência do fenómeno de Deus à margem da efetividade da revelação dada no acontecimento da ressurreição como transformação de si mesmo por um outro. Nesse sentido, elogia a proposta implícita de Marion em unir a possibilidade da tarefa filosófica com a efetividade da revelação teológica, acrescentando que este autor não tem de esconder a produtividade deste diálogo, nem a força da teologia nas suas categorias fenomenológicas ${ }^{98}$.

Jean-Luc Marion desenvolve uma fenomenologia que promove uma ampliação da racionalidade, recusando a redução desta à razão científica que exclui tudo o que não lhe pertence para os campos do irracional, da crença ou da fé. Acaba por superar a oposição entre fé e razão e socorre-se da teologia para ampliar a racionalidade filosófica, tal como se pode verificar pelas diversas categorias da fenomenologia da doação. Mas isso não diminui o seu valor filosófico, porque atuam na imanência do âmbito fenomenológico, tal como acontece com a categoria do amor que exige uma hermenêutica que opera a partir de uma outra lógica. Detendo-se no inaparente ou invisível presente em todo o aparecer, convertendo em fenómeno o que está oculto, a fenomenologia de Marion exige a intervenção de um pensamento que não é mediação reflexiva nem especulação e que também não é visão imediata ou intuição daquilo que é o objeto.

Para tal, traduz a lógica do silêncio da tautologia de Heidegger na lógica do amor da doação, impondo a sua própria lógica, o seu âmbito e a sua ordem. $\mathrm{O}$ amor dá-nos acesso à automostração do fenómeno, pois constitui-se numa abertura permanente a isso que se dá a partir de si mesmo: por via do amor, a inaparência vem à presença e o acontecer do fenómeno desvela-se, não no modo

97 Roberto J. Walton, "El giro teológico como retorno a los orígenes: La fenomenologia de la excedência", Pensamiento y Cultura, 13, 2 (2010), 128.

98 Emmanuel Falque, "Le Haut Lieu du soi: une disputatio théologique et phénoménologique (autor du saint Augustin de J.-L. Marion)", Revue de Métaphysique et de Morale, 63, 3 (2009), 363-390. 
objetivo e conceptual, mas no modo fenomenológico trans-conceptual e mistérico. Em respeito às perguntas decisivas para a humanidade e no reconhecimento de que antes de ser um ens cogitans ou um ens volens, o homem é um ens amans, esta fenomenologia hermenêutica do amor permite abrir os olhos para o mundo do acontecer originário ${ }^{99}$.

\section{REFERENCIAS BIBLIOGRÁFICAS}

Aristóteles. Ética a Nicómaco. Lisboa: Quetzal Editores, 2004.

Balthasar, Hans Urs von. Theodramatik. V. Das Endspiel. Einsiedeln: Johannes Verlag, 1983.

Balthasar, Hans Urs von. Theologik II Wahrheit Gottes. Einsiedeln: Johannes Verlag, 1985.

Balthasar, Hans Urs von. Só o Amor é digno de Fé. Lisboa: Assírio \& Alvim, 2008.

Benoist, Jocelyn. "Le "tournant théologique"”. In L'idée de phénoménologie, ed. Jocelyn Benoist. Paris: Beauchese, 2001.

Courtine, Jean-François. "L'idée de la phénomenologie et la problématique de la réduction". In Phénomenologie et métaphysique, ed. Jean-Luc Marion et Guy Planty-Bonjour. Paris: PUF, 1984.

Emmanuel Falque. "Le Haut Lieu du soi: une disputatio théologique et phénoménologique (autor du saint Augustin de J.-L. Marion)". Revue de Métaphysique et de Morale, 63, 3 (2009): 363-390.

Falque, Emmanuel. Le combat amoureux. Disputes phénoménologiques et théologiques. Paris: Hermann, 2014.

Falque, Emmanuel. Passer le Rubicon. Philosophie et Théologie: essai sur les fronteires. Bruxelles: Lessius, 2013.

Grondin, Jean. "La tension de la donation ultime et de la pensée herméneutique de l'application chez Jean-Luc Marion". Dialogue. Revue canadienne de philosophie, 38, n. 3 (1999): 547-559.

Heidegger, Martin. Gesamtausgabe, 2. Frankfurt: Vittorio Klostermann Verlag, 1989.

Husserl, Edmund. Husserliana. Gesammelte Werke, Dokumente und Materialen, I. Den Hagg: Martinus Nijhoff Publishers, 1950.

Janicaud, Dominique. "Le tournant théologique de la phénoménologie française". In La phénoménologie dans tous ses états, ed. Dominique Janicaud. Paris: Gallimard, 2009.

Lubac, Henri de. Corpus Mysticum, L'Eucharistie et l'Eglise au moyen age. Paris: Aubier, 1948.

99 Cf. Jean-Luc Marion, Prolégomènes à la charité (Paris: Éditions de la Différence, 1986), 88. 
Kant, Immanuel. Crítica da Razão Pura. Lisboa: Fundação Calouste Gulbenkian, 1989.

Laruelle. François. "L'appel et le phénomène". Revue de Métaphysique et Morale 96, 1 (1991): 27-42.

Levinas, Emmanuel. Le temps et l'autre. Paris: PUF, 1983.

Marinescu, Paul. "L'universalité et les "sans fin" de l'herméneutique: Jean-Luc Marion, lecteur de Ricoeur". In, Lectures de Jean-Luc Marion, edition de Christian Ciocan et Anca Vasilou. Paris: Cerf, 2016.

Marion, Jean-Luc. "Remarques sur l'utilité en théologie de la phénomenologie". In, Filosofia y Teologia en diálogo desde América Latina. Homenaje a Juan Carlos Scannone en su 80 cumpleaños, ed. José Cantó, José Maria Figueroa. Córdoba: EDUCC, 2013.

Marion, Jean-Luc. Au lieu de soi, l'aproche de Saint Augustin. Paris: PUF, 2008.

Marion, Jean-Luc. "Ce mystère qui juge celui qui le juge". Résurrection, 32 (1970), 54-78.

Marion, Jean-Luc. Certitudes negatives. Paris: Grasset et Fasquelle, 2010.

Marion, Jean-Luc. Coubert ou la peinture à l'oeil. Paris: Flammarion, 2014.

Marion, Jean-Luc. De surcroit. Études sur les phénomènes saturés. Paris: PUF, 2010.

Marion, Jean-Luc. Étan donné - Essai d'une phénoménologie de la donation. Paris: PUF, 2023.

Marion, Jean-Luc. Figures de phénoménologie: Husserl, Heidegger, Levinas, Henry, Derrida. Paris, Vrin, 2012.

Marion, Jean-Luc. Givennes ad Revelation. Oxford: Oxford University Press, 2016.

Marion, Jean-Luc. "La connaissance de la charité". Communio, XIX, 6 (1994), $27-42$.

Marion, Jean-Luc. L'idole et la distance. Cinq études. Paris: Grasset, 1977.

Marion, Jean-Luc. La croisée du visible. Paris: Éditions de la Différence, 1991.

Marion, Jean-Luc. La rigueur des choses. Entretiens avec Dan Arbib. Paris: Flammarion, 2012.

Marion, Jean-Luc. Le phénomène érotique. Paris: Grasset, 2003.

Marion, Jean-Luc. Le visible et le révélé. Paris: Cerf, 2005.

Marion, Jean-Luc. Le coire pour le voir. Paris: Cmmunio Parole et Silence, 2010.

Marion, Jean-Luc. “Le présent et le don”. Communio, II, 6 (novembre 1977), 50-70.

Marion, Jean-Luc. Prolégomènes à la charité. Paris: Éditions de la Différence, 1986.

Marion, Jean-Luc. Réduction et donation. Recherches sur Husserl, Heidegger et la phénoménologie. Paris: PUF, 1989.

Marion, Jean-Luc. Sur la théologie blanche de Descartes. Analogie, création des vérités éternelles. Paris: PUF, 1981. 
Marion, Jean-Luc. Sur le prisme métaphysique de Descartes. Constitution et limites de l'onto-thé-logie cartésienne. Paris: Puf, 1986.

Martin, Javier San. La estrutura del método fenomenológico. Madrid: Universidad Nacional de Educación a Distancia, 1986.

Restrepo, Carlos Henrique. "El 'giro teológico' de la fenomenologia. Introducción al debate". Pensamiento y Cultura 13, 2 (2010):115-126.

Ricard, Marie-André. "La question de la donation chez Jean-Luc Marion". Laval Théologie et philosophie, 57 (2001): 83-94.

Roggero, Jorge Luis. Hermenéutica del amor - La fenomenologia de la donación de Jean-Luc Marion en diálogo com la fenomenologia del joven Heidegger. Buenos Aires: Sb editorial, 2019.

Romano, Claude. "Remarques sur la méthode phénoménologique dans Étant donné de Jean-Luc Marion". Annales de philosophie, 21 (2000):6-14.

Scannone, Juan Carlos. "Outro como si mesmo. El llamado y el responsório según Jean-Luc Marion". In Jean-Luc Marion: limites y possibilidades de la Filosofia y de la Teologia, ed. Jorge Luis Roggero. Buenos Aires: SB Editorial, 2017.

Scannone, Ruan Carlos. "Fenomenologia y hermenêutica en la fenomenologia de la donación de Jean-Luc Marion". Stromata, 61, 3-4 (2005):179-193.

Tabet, Pascale. Amour et donation chez Jean-Luc Marion. Une phénoménologie de l'excès. Paris: L'Harmattan, 2017.

Verdú, Ignacio. "Amor y metafísica. Un a reflexión acerca de la filosofía primera". Cauriensia 14 (2019): 117-130.

Vinolo, Stéphane. "Jean-Luc Marion: escribir la ausência. El 'giro teológico' como porvenir de la filosofia", Escritos 20, 45 (2012):275-304.

Walton, Roberto. “El giro teológico como retorno a los orígenes: La fenomenologia de la excedência". Pensamiento y Cultura, 13, 2 (2010):127140.

Walton, Roberto. "Teleologia y teologia en Edmund Husserl". Estudios de Filosofia, 45 (2012):81-104.

Samuel Fernando Rodrigues Dimas Centro de Estudos Filosóficos e Humanísticos $\mathrm{Rf}^{\text {a }}$ UIDB $/ 00683 / 2020$, FCT

Faculdade de Ciências Humanas Universidade Católica Portuguesa

Palma de Cima, 1649-023

Lilsboa (Portugal)

https://orcid.org/0000-0002-0968-3616 